\title{
Research and Development on Optimal Expenditures Evaluation and Prediction: Case Study of Iran's Agricultural Sector
}

\section{Habib Shahbazi ${ }^{1 *}$, Seyed Safdar Hosseini ${ }^{2}$, Sajjad Shamshiri ${ }^{3}$}

'Department of Agricultural Economics, Sayyed Jamaleddin Asadabadi University (SJAU), Hamedan, Iran

${ }^{2}$ Department of Agricultural Economics, University of Tehran (UT), Tehran, Iran

${ }^{3}$ Department of Agricultural Sciences, Sayyed Jamaleddin Asadabadi University (SJAU), Hamedan, Iran

Study Area: Bandar Abbas, Iran

Coordinates: $27^{\circ} 11^{\prime} \mathrm{N} ; 56^{\circ} 16^{\prime} \mathrm{E}$

Key words: Agricultural Sector, Agriculture policies

JEL Classification: $\mathrm{Co1}, \mathrm{I}_{3} 8, \mathrm{O}_{32}$.

\begin{abstract}
Optimal management practices in the agriculture sector would never be possible in absence of a proper policy on the use of actual and potential sources of production, production methods, control and monitor production processes. Thus, it is necessary to review agricultural policies in order to formulate appropriate strategies to achieve the optimum conditions of production focused efforts. One of these policies is R\&D (Research and Development). In Iran, most of the researchers have considered the ex-post evaluation of R\&D expenditures in their studies. In this study, a mixed ex-post and ex-ante evaluation of $R \& D$ approach were used for the year between 1959-2010. Results revealed that the current budget of R\&D had increased agricultural sector supply by approximately 19.3 percent. The rate of return, in this case was 26.94 percent. But if agricultural R\&D spending increases on average 31.55 percent, supply may shift by 8.11 percent and the rate of return would be equivalent to 28.17 percent. According to these results, annual $R \& D$ optimal expenditures during Iran Development Plan \#5 and 6, on average, are predicted as equal to 8177.2 and $13158.9 \mathrm{Bil} \mathrm{Rls}$ (local currency), respectively.
\end{abstract}

2.76, France 2.24 and Germany 2.89 percent. In Asian countries like Japan were 3.39, South Korea 4.03, Singapore 2.61, and Taiwan 2.63 percent. In the North American countries such as Canada and U.S., the percentage was 1.78 and 2.68, respectively (World Bank Report, 2014). In the agriculture sector, the world's R\&D investment has increased from 14.24 billion in 1981 to 31.70 billion US dollars in 2008 (Bienetema, et al., 2012). Recent trends in farm productivity and rising of food prices concerns that whether the era of global agricultural abundance is over. In Iran, agriculture R\&D budget shows an increment from 1184 Mil Rls (local currency) in 1972 to 2576 Bil Rls in 2012, making the average annual growth 19.6 percent. Nevertheless, it must be kept in mind that the overall share of R\&D in Iran's total GDP is very small. The average share of R\&D funding in the years 1959-2012 was 0.22 which reached 0.48 in 2012 (Hosseini, et al., 2015). Most economic evaluations performed on R\&D investments in developed countries have shown that efficiency is very high in this sector and R\&D budgets are growing in this 
country. The main target of this paper is to assess the economic models used to evaluate the effects of agricultural R\&D investing in Iran. For this reason, ex-post evaluations are performed in order to obtain optimal agricultural R\&D expenditures and to evaluate the effects of R\&D expenditures on the supply of agricultural sector. Ex-ante evaluations arealso performed to assess the effects of agricultural $R \& D$ expenditures on the supply and productivity of the agricultural sector. Also, spillover agricultural education effects on the productivity of the agricultural sector will be assessed.

\section{Materials and methods:}

In order to estimate agricultural optimal R\&D expenditures and to evaluate agricultural current and optimal R\&D expenditures, aggregate agricultural demand and supply would be needed to know. Agricultural R\&D affects the agricultural supply through their impact on agricultural productivity. An increase in $R \& D$ expenditures would be expected to increase productivity in subsequent years and hence shift the supply curve to the right at all price levels (White \& Havlicek, 1982). This increase in supply is the result of a decline in price. We use these properties to identify the target function for achieving optimal R\&D expenditures. In other words, the target is projected by shifts in supply and declines in price. Hence, we identify the desired price that is proven shifted supply by optimal R\&D expenditures. So, the price is the target variable and R\&D expenditures are the control variable achieved by the minimization of the deviation of current price and desired price. Turnovsky (1974) and White \& Havlicek (1982) used a quadratic cost function. Restriction of target function is the equilibrium of supply and demand. Demand and supply should be sufficiently flexible through time. We assumed that both quantities of demand and supply are a function of current and lagged prices and other determinants formed as Koyck distributed lag model as Hosseini \& Shahbazi (2013). So, we could estimate short and long run variable effects.

By inserting productivity variable GsPI as Hosseini et al. (2015) in supply model, we achieve target and restriction functions that result in optimal $R \& D$ expenditures, quantity and price as follows in logarithmic form (Shahbazi, 2012):

$$
\begin{aligned}
& \text { Min } \mathrm{DT}=\sum_{\mathrm{t}-1}^{\mathrm{T}}\left(\xi \mathrm{P}_{\mathrm{t}}^{\prime}\right)^{2} \\
& \text { S.T. } \quad Q_{t}^{\prime}=\frac{\beta_{\mathrm{d}}}{\mu-\lambda}\left(\frac{\mathrm{P}_{\mathrm{t}}-\alpha_{\mathrm{d}}}{\Omega}\right)^{\prime} \frac{\beta_{\mathrm{s}}}{\mu-\lambda}\left(\frac{\mathrm{P}_{\mathrm{t}}-\alpha_{\mathrm{s}}}{\psi}\right)^{\prime}+\sum_{\mathrm{i}=1}^{\mathrm{I}} \frac{(1-\lambda) \theta_{\mathrm{di}}}{(\mu-\lambda)\left(1-\delta_{\mathrm{i}}\right.} \mathrm{G}_{\mathrm{dit}}^{\prime} \\
& \sum_{\mathrm{j}=2}^{J} \frac{(1-\mu) \theta_{\mathrm{sj}}}{(\mu-\lambda)\left(1-\eta_{\mathrm{j}}\right)} G_{\mathrm{sjt}}^{,}+\frac{\theta_{\mathrm{PI}}(\mu-1)}{(\mu-\lambda)} \\
& X\left(\sum_{t=2}^{\mathrm{L}} \omega_{2} \mathrm{R}_{\mathrm{t}-\mathrm{t}-1}^{\prime}+\sum_{\mathrm{o}=1}^{\mathrm{O}} \mathrm{v}_{0} \mathrm{FSIR}_{\mathrm{t}-\mathrm{-}-1}^{\prime}+\sum_{\mathrm{v}=1}^{\mathrm{V}} \varepsilon_{\mathrm{v}} \operatorname{ISIR}_{\mathrm{t}-\mathrm{v}-\mathrm{t}}^{\prime}+\rho_{\mathrm{t}} \mathrm{E}_{\mathrm{t}}^{\prime}+\rho_{2} \mathrm{~W}_{\mathrm{t}}^{\prime}\right)
\end{aligned}
$$

By estimating the optimal $R \& D$ expenditures, quantity, price and productivity function, the shift parameter of current (K1) and optimal $R \& D\left(K^{*}\right)$ expenditures can be calculated following Hosseini et al. (2015) and Shahbazi (2012), respectively. We estimated $\mathrm{K}$ shift parameter (current and optimal) for the calculation of current and optimal GARB. For this, we had to find long-run inverse demand and supply functions. By calculating supply without the R\&D expenditures and supply with optimal R\&D expenditures, GARB in both situations can be calculated. For evaluating R\&D expenditures in current and optimal situations, we use IRR (internal rate of return), B/C (benefit-cost) and NPV (net present value) indices for current and optimal R\&D.

\section{Results:}

AIn the estimation of R\&D optimal expenditures, first of all, we need productivity relations (Hosseini \& Shahbazi, 2015). Iran's annual agricultural R\&D expenditures (R), annual agricultural education and promotion expenditures (E), annual non-agricultural R\&D expenditures (as domestic spill in-FSIR), annual agricultural imported capital formation (as external spill in- ISIR), annual agricultural imported intermediate input (as external spill in- ISIR) and annual weather (rain fall-W) were seen to be affective variables on agriculture productivity for years of 1959-2010. Iran's agricultural sector productivity index was estimated and calculated by Shahbazi (2012) using the Solow (1957)'s residual model. We used Hosseini et al. (2015)'s estimated model as productivity model which indicated that the R\&D had the least effect under present conditions. However, these effects were improved over time. In lag 4 , the maximum effectiveness occurs. The effects of R\&D decrease as they reached in lag 8. The total effects of Iran's annual agricultural R\&D expenditures, annual non-agricultural R\&D expenditures (as domestic spill over), annual agricultural imported capital formation (as external spill over) and annual agricultural imported intermediate input (as external spill in) are 31.11, 10.89, 5.68 and 4.62 percent, respectively. According to Hosseini \& Shahbazi (2013), productivity growth coefficient in supply relation was 0.62 and thus, we could calculate the K Parameter of current effects of R\&D. The K parameter for Iran's annual agricultural R\&D expenditures, annual non-agricultural R\&D expenditures (as domestic spill over), annual agricultural imported capital formation (as spill over) and annual agricultural imported intermediate input (as spill over) were 19.3, 6.8, 4.3 and 2.9, respectively.

After productivity relation estimation, we needed demand and supply. Hosseini \& Shahbazi (2013) estimated short-run own price, income and imported price demand elasticities as -0.118, 0.135 and -0.099, respectively. Longrun demand of own price, income and imported price were $-0.162,0.182$ and -0.122 , respectively. Also, they estimated 
short-run own price, input price and exported price supply as $0.129,-0.123$ and 0.103 , respectively. Long-run supply of own price, input price and exported price were o.166, -0.142 and 0.128 , respectively.

By using these equation (1), we estimate optimal agricultural R\&D expenditures, price index and aggregate supply as shown in Table 2 for 1967-2010. For comparison of optimal quantity with current condition, we mentioned current agricultural $\mathrm{R} \& \mathrm{D}$ expenditures, price index and aggregate supply. $\mathrm{K}$ parameter as percentage is shown in Table-1.

Results show that if R\&D expenditures increase by 31.55 percent on average, agricultural supply would increase more than 8.11 percent. That's mean optimal supply would be 8.11 percent more than current supply, if we investigate optimal R\&D expenditures level instead of current R\&D expenditure then, based on results from Table 1, GARB of current and optimal expenditures could be estimated. Based on the estimated GARB, current and optimal R\&D expenditures, and dynamicity effect of GARB shown in Alston et al. (2010) and Shahbazi (2012), NPV, $\mathrm{B} / \mathrm{C}$ and IRR of Current and optimal expenditures has been evaluated for two scenarios of 14 (governmental loan rate) and 20 (governmental bond rate) percent as discount rate in Table 2.

Results in Table 4 indicate that the IRR of current R\&D projects is 26.94 percent and the IRR of the optimal $R \& D$ expenditures would be 28.17 percent. Benefit-cost ratio for a 14 percent discount rate is 2.98 under current $R \& D$ expenditures but would be 3.50 for optimal R\&D expenditures.

After estimating and financial evaluating of current and optimal R\&D expenditures for years of 1967-2010, Iran's agricultural price index, $R \& D$ expenditures and aggregate supply were predicated by two scenarios (current and optimal R\&D expenditures trends) for years of $5^{\text {th }}$ and 6th Iran development plan (2011-2020). According to Table 5, price index average for 5 th and 6th Iran Development Plan will be 974.7 and 2096.4 in current trend scenario, respectively. But price index average for $5^{\text {th }}$ and 6th Iran Development Plan will be 660.5 and 1380.9 in optimal trend scenario, respectively. R\&D expenditures average for $5^{\text {th }}$ and 6th Iran Development Plan would be 4460.4 and 6905.5 in current trend scenario. But average price index for 5 th and 6 th respective Iran Development Plan would be 8177.2 and 13158.9 in optimal trend scenario.

Table2. Current and optimal price index, aggregate supply and R\&D expenditures (1997=100)

\begin{tabular}{|c|c|c|c|c|c|c|c|c|c|}
\hline & \multicolumn{3}{|c|}{ Current Condition } & \multicolumn{3}{|c|}{ Optimal Condition } & \multicolumn{3}{|c|}{ K Parameter (percent) } \\
\hline Year & $\begin{array}{l}\text { Price } \\
\text { index }\end{array}$ & $\begin{array}{l}\text { Aggregate } \\
\text { Supply }\end{array}$ & $\begin{array}{l}\text { R\&D } \\
\text { Expenditures }\end{array}$ & $\begin{array}{l}\text { Price } \\
\text { index }\end{array}$ & $\begin{array}{l}\text { Aggregate } \\
\text { Supply }\end{array}$ & $\begin{array}{l}\text { R\&D } \\
\text { Expenditures }\end{array}$ & $\begin{array}{l}\text { Price } \\
\text { index }\end{array}$ & $\begin{array}{l}\text { Aggregate } \\
\text { Supply }\end{array}$ & $\begin{array}{l}\text { R\&D } \\
\text { Expenditures }\end{array}$ \\
\hline 1967 & 1.26 & 13776 & 275 & 1.25 & 13917 & 339 & 0.79 & 1.02 & 23.27 \\
\hline 1968 & 1.21 & 15629 & 377 & 1.12 & 15810 & 444 & 7.13 & 1.16 & 17.77 \\
\hline 1969 & 1.22 & 16115 & 517 & 1.06 & $1775^{8}$ & 579 & 13.11 & 10.19 & 11.99 \\
\hline 1970 & 1.14 & 18151 & 699 & 1.03 & 18300 & 856 & 9.89 & 0.82 & 22.46 \\
\hline 1971 & 1.39 & 17501 & 979 & 1.2 & 17989 & 1134 & 13.79 & 2.79 & 15.83 \\
\hline 1972 & 1.48 & 19584 & 1295 & 1.3 & 21677 & 1526 & 12.34 & 10.69 & 17.84 \\
\hline 1973 & 1.71 & 20050 & 1734 & 1.63 & 20137 & 2189 & 4.85 & 0.43 & 26.24 \\
\hline 1974 & 2.15 & 18606 & 1849 & 2.1 & 20993 & 2337 & 2.46 & 12.83 & 26.39 \\
\hline 1975 & 2.09 & 20671 & 2261 & 2 & 21629 & 2587 & 4.21 & 4.64 & 14.42 \\
\hline 1976 & 2.41 & 24784 & 2575 & 2.15 & 26388 & 3099 & 10.64 & 6.47 & 20.35 \\
\hline 1977 & 2.67 & 22863 & 2130 & 2.35 & 22895 & 2634 & 11.85 & 0.14 & 23.66 \\
\hline 1978 & 3.24 & 22922 & 1544 & 3.1 & 23043 & 1846 & $4 \cdot 32$ & 0.53 & 19.56 \\
\hline 1979 & 4.03 & 23847 & 1144 & 3.87 & 25273 & 1428 & 4.02 & 5.98 & 24.83 \\
\hline 1980 & 5.17 & 24823 & 1265 & 5.07 & 25403 & 1557 & 1.88 & 2.34 & 23.08 \\
\hline 1981 & $7 \cdot 39$ & 25206 & 812 & 6.6 & 26035 & 1043 & 10.65 & 3.29 & 28.45 \\
\hline 1982 & 8.5 & 28027 & 725 & 8.5 & 30080 & 920 & -0.04 & $7 \cdot 33$ & 26.9 \\
\hline 1983 & 9.08 & 31236 & 1402 & 8.05 & 32787 & 1765 & 11.3 & 4.96 & 25.89 \\
\hline 1984 & 10.21 & 31970 & 1385 & 8.2 & 33085 & 1879 & 19.69 & 3.49 & 35.67 \\
\hline 1985 & 10.41 & 34630 & 1781 & 8.6 & 37869 & 2306 & 17.4 & $9 \cdot 35$ & 29.48 \\
\hline 1986 & 12.03 & 35218 & 1694 & 10.53 & $355^{26}$ & 2058 & 12.45 & 0.87 & 21.49 \\
\hline 1987 & $15 \cdot 3$ & 37815 & 1500 & 13.2 & 38857 & 2032 & 13.73 & 2.76 & 35.47 \\
\hline 1988 & $15 \cdot 37$ & 37940 & 1347 & 13.7 & 39676 & 1861 & 10.85 & 4.58 & 38.16 \\
\hline 1989 & 18.95 & 39636 & 1370 & 16.9 & 41674 & 1846 & 10.83 & 5.14 & 34.74 \\
\hline 1990 & 19.15 & 44081 & 2132 & 16.4 & 46424 & 2827 & 14.38 & $5 \cdot 32$ & 32.6 \\
\hline 1991 & 24.29 & 46637 & 2075 & 18.2 & 50059 & 2900 & 25.06 & $7 \cdot 34$ & 39.76 \\
\hline 1992 & 29.99 & 51469 & 2278 & $25 \cdot 3$ & 56540 & 3077 & 15.64 & 9.85 & 35.07 \\
\hline 1993 & 37.76 & 52303 & 2811 & 32.8 & 52746 & 3520 & 13.12 & 0.85 & 25.22 \\
\hline 1994 & 49.73 & 53501 & 2077 & 46.8 & 57654 & 2883 & 5.89 & 7.76 & 38.81 \\
\hline
\end{tabular}


Ambient Science, 2016: Vol. 03(Sp2); 05-08

DOI:10.21276/ambi.2016.03.sp2.ta01

TECHNOSCIENCE ARTICLE

\begin{tabular}{|c|c|c|c|c|c|c|c|c|c|}
\hline 1995 & 78.69 & 55456 & 1704 & 67.6 & 65737 & 2316 & 14.09 & 18.54 & 35.92 \\
\hline 1996 & 89.28 & 56890 & 2815 & 78 & 62932 & 3970 & 12.63 & 10.62 & 41.03 \\
\hline 1997 & 100 & 57615 & 3459 & 88 & 64721 & 4565 & 12 & 12.33 & 31.97 \\
\hline 1998 & 115.99 & 63218 & 3385 & 94.8 & 67676 & 4507 & 18.27 & 7.05 & 33.15 \\
\hline 1999 & 146.55 & 58777 & 2857 & 124.4 & 66050 & 3901 & 15.11 & 12.37 & 36.54 \\
\hline 2000 & 170.52 & 60328 & 2690 & 149 & 63509 & 3667 & 12.62 & 5.27 & 36.32 \\
\hline 2001 & 184.14 & 60333 & 4122 & 179.1 & 70872 & 5806 & 2.74 & 17.47 & 40.85 \\
\hline 2002 & $209 \cdot 75$ & 67905 & 3448 & 184.3 & 78937 & 4864 & 12.13 & 16.25 & 41.07 \\
\hline 2003 & 233.7 & 71721 & 3198 & 197.6 & 86802 & 4524 & 15.45 & 21.03 & 41.46 \\
\hline 2004 & 280.01 & 72691 & 2956 & 228.5 & 84174 & 3789 & 18.4 & 15.8 & 28.18 \\
\hline 2005 & 288.05 & 78689 & 3262 & 230.7 & 95670 & 4355 & 19.91 & 21.58 & 33.51 \\
\hline 2006 & 329.91 & 82110 & 3640 & 256.6 & 101438 & 5470 & 22.22 & 23.54 & 50.27 \\
\hline 2007 & 401.23 & 87073 & 3957 & 297.5 & 95238 & 5209 & 25.85 & $9 \cdot 38$ & 31.64 \\
\hline 2008 & 513.6 & 76799 & 3493 & 378.4 & 93017 & 5065 & 26.32 & 21.12 & 45 \\
\hline 2009 & $547 \cdot 99$ & 87166 & 3536 & 391.8 & 95801 & 5202 & 28.5 & $9 \cdot 91$ & 47.13 \\
\hline 2010 & 601.37 & 94837 & 3405 & 415.2 & 96585 & 6091 & 30.96 & 1.84 & 78.88 \\
\hline$\overline{\text { Average }}$ & $\overline{104.3}$ & 44559 & 2135 & $\overline{82.38}$ & 49076 & $\overline{2881}$ & 12.94 & $\overline{8.11}$ & $\overline{31.55}$ \\
\hline
\end{tabular}

Table4. Current and optimal R\&D expenditures evaluation

\begin{tabular}{llll}
\hline & Current R\&D & Added R\&D & Optimal R\&D \\
\hline NPV ( o.14) & 16281 & 9079 & 25360 \\
NPV ( o.20) & 3329 & 2106 & 5434 \\
B/C (o.14) & 2.98 & 5.74 & 3.5 \\
B/C (o.20) & 1.67 & 3.3 & 1.9 \\
IRR & $26.94 \%$ & $32.05 \%$ & $28.17 \%$ \\
\hline
\end{tabular}

Table 3. Prediction of Iran's agricultural price index, R\&D expenditures and aggregate supply for 2011-2020 (1997=100)

\begin{tabular}{lllllll}
\hline & \multicolumn{3}{c}{ According to optimal trend } & \multicolumn{3}{l}{ According to Current trend } \\
\hline Year & $\begin{array}{l}\text { Price } \\
\text { Index }\end{array}$ & $\begin{array}{l}\text { R\& D } \\
\text { Exendi. }\end{array}$ & $\begin{array}{l}\text { Aggregate } \\
\text { Supply }\end{array}$ & $\begin{array}{l}\text { Price } \\
\text { Index }\end{array}$ & $\begin{array}{l}\text { R\& D } \\
\text { Exendi. }\end{array}$ & $\begin{array}{l}\text { Aggregate } \\
\text { Supply }\end{array}$ \\
\hline 2011 & 700.9 & 3716.4 & $99377 \cdot 5$ & 481.2 & 6699.4 & 101322.4 \\
2012 & 816.9 & 4055.9 & 104135.3 & 557.7 & 7368.1 & 106292.6 \\
2013 & 952.2 & 4426.5 & 109120.8 & 646.3 & 8103.7 & 111506.5 \\
2014 & 1109.8 & 4830.8 & 114345 & 749 & 8912.6 & 116976.2 \\
2015 & 1293.5 & 5272.1 & 119819.4 & 868.1 & 9802.3 & 122714.2 \\
2016 & 1507.6 & 5753.8 & 125555.8 & 1006.1 & 10780.8 & 128733.7 \\
2017 & 1757.1 & 6279.4 & 131566.9 & 1166 & 11857 & 135048.4 \\
2018 & 2048 & 6853.1 & 137865.7 & 1351.3 & 13040.6 & 141672.9 \\
2019 & 2387 & 7479.1 & 144466.1 & 1566.1 & 14342.3 & 148622.3 \\
2020 & 2782.1 & 8162.3 & 151382.5 & 1815 & 15774 & 155912.7 \\
Growth rate & 16.6 & 9.1 & 4.8 & 15.9 & 10 & 4.9 \\
$(2011-15)^{*}$ & 974.7 & 4460.4 & 109359.6 & 660.5 & 8177.2 & 111762.4 \\
$(2016-20)^{* *}$ & 2096.4 & 6905.5 & 138167.4 & 1380.9 & 13158.9 & 141998 \\
\hline
\end{tabular}

Average of 5 th* $^{*}$ and 6 th $^{* *}$ Iran' development plan

\section{Conclusions:}

The Iranian government has used $R \& D$ policies for the further development of the agricultural sectors. This is achieved through public investment in agricultural R\&D which requires the establishment of public $R \& D$ bodies and allocation of annual R\&D budgets (Hosseini et al, 2009). But in the annual budget, this problem has not been regulated. Results show that the current budget of R\&D has increased supply by approximately 19.3 percent. The rate of return, in this case, is 26.94 percent. However, if agricultural research spending increases by an average of 31.55 percent, supply would increase by approximately 8.11 percent and thus its rate of returns would be equivalent to 28.17 percent. These results indicate that the optimal R\&D budget is much higher than the current $R \& D$ budget, i.e., current $R \& D$ budget is not optimal. Government and agricultural policy makers should be considering optimal R\&D budget. With a suitable budget, maximum development in the agricultural sector can be achieved. According to these result, annual R\&D optimal expenditures for years of 5 th and 6th Iran's development plan are predicted that is equal to 8177.2 and 13158.9 Bil Rls, respectively (on average)

\section{References:}

Alston, J., Parady, P., James, J. \& Anderson, M. (2010): The economics of agricultural R\&D. Ann.Rev. Res. Econ., 1:537565.

Bienetema, N., Stads, G., Fuglie, K. \& Heisey, P. (2012): ASTI Global Assessment of Agricultural R\&D Spending: Developing Countries Accelerate Investment. Report: International Food Policy Research Institute, 1-24.

Hosseini, S., Hassanpour, E. \& Sadeghian, S. (2009): An economic evaluation of Iranian public agricultural R\&D Policy: The case of Sugar Beet. Res. Policy, 38(9):1446-1452.

Hosseini, S. \& Shahbazi, H. (2013): Estimation of Iran's agricultural aggregate demand and supply: 1959-2007. J. Agri. Econ. Dev., $27(1): 16-24$

Hosseini S., Shahbazi H. \& Abbasifar A. (2015): R\&D Spillovers Impact on Productivity (Case study: Iran's agricultural sector). Prod. Manag., 8(33):47-76.

Shahbazi, H. (2012): Economic evaluation of Iran's agricultural R\&D. Tehran: Ph. D Dissertation, Agricultural Economic and Developing Faculty, Agriculture and Natural Resources College. University of Tehran.

Solow, R. (1957): Technical change and aggregate production function. Rev. Econ. and Stat., 5(3):312-320.

Turnovsky, S. (1974): The Instability properties of optimal economic policies. Am. Econ. Rev., 64:136-148.

White, F. \& Havlicek, J. (1982): Optimal expenditure for agricultural research and extension: Implication of underfunding. Am. J. Agri. Econ., 47-55. 